\title{
Cracks in Open Collaboration in Universities
}

U NIVERSITIES AND THE interchange of scholars and students in international collaborations have long played an important role in knitting a fabric of human relationships and shared understanding. This fabric is fraying rapidly.

In recent Communications' editorials (January and September 2019), I called out rising political tensions and conflict that challenge international open collaboration in the university. My objective was to inspire the computing community to come together and address these rising challenges.

In the past six months, the situation has worsened with accelerating economic decoupling betwixt China and the U.S., increasing political conflict, and the persistent reality that China's political system is not evolving toward openness or democracy. Instead, China's growing economic and military strength appears to embolden assertion of international power and internal crackdowns. ${ }^{\mathrm{a}, \mathrm{b}, \mathrm{c}, \mathrm{d}}$ Analysts increasingly opine that China lacks the internal civil stability essential to be a good global economic partner. The U.S. has moved to restrict technology flow and investment from allies to China. Directly, a growing strategic consensus believes competition between U.S. and

a I. Ali. Pentagon says China missile test in South China Sea 'disturbing.' Reuters, July 2, 2019.

b C. Buckley and C. Horton. Xi Jinping warns Taiwan that unification is the goal and force is an option. New York Times, Jan. 1, 2019.

c L. Beachum. Uighurs and their supporters decry Chinese 'concentration camps,' 'genocide' after Xinjiang documents leaked. Washington Post, Nov. 17, 2019.

d J. Griffiths, R. Wright, B. Westcott and H. Regan. Protesters try to escape Hong Kong university after violent night. CNN, Nov. 18, 2019.
China is shaping the world into two Internets, separated by a new "Berlin wall." These two models for the Internet differ in control (government control vs. open), companies (Baidu/ Tencent/Alibaba vs. Google/Facebook/ Amazon), and increasingly on their technology base. ${ }^{f}$

\section{What Are the Implications?}

U.S. government actions to restrict technology flow (export control) are reducing the ability of universities to collaborate with some foreign corporations and organizations. Programs instituted to combat intellectual property theft create new reporting requirements. Funded research by corporations on the "entity list" is prohibited, causing Huawei to disband its U.S. research organization. ${ }^{g}$ Collectively, these actions have a chilling impact on collaboration and create rising anxiety. China's government-rhetoric and action against its own citizens in Xinjiang and Hong Kong reminds the world the government maintains power by force within China and through intimidation campaigns abroad. The resulting tensions produce covert and overt suppression of open communication and learning. ${ }^{\mathrm{h}, \mathrm{i}, \mathrm{j}}$

e T.J. Friedman. The world-shaking news that you're missing: The U.S.-China divide isn't just about trade. New York Times, Nov. 26, 2019.

f J. Bernstein. The American Internet sucks. The alternative Is China. Buzzfeed News, Nov. 17, 2019.

g Huawei's U.S. research arm slashes more than $70 \%$ of workforce. The Straits Times, July 23, 2019.

h I. Kwai. What Chinese students abroad really think about Hong Kong's protests. New York Times, Sept. 17, 2019.

i Hong Kong protests: Sheffield university students clash. BBC News, Oct. 2, 2019.

j M. Melia. Tensions over Hong Kong unrest flare on US college campuses. AP, Oct. 2, 2019.
There is surprising growth of Internet application bubbles that feed Chinese students abroad a steady stream of censored facts and spin from behind the "Great Firewall"; see, for example, "College Daily."k

\section{How Can We Protect Collaboration?}

In a peacefully integrated and globalized world, nationality need not be apparent. In a world with national military and "no rules" economic competition, nationality takes on critical importance in technologies of direct military and economic importance-such as many dimensions of computing (AI, cybersecurity, HPC). In such a world, we must do three things to protect open collaboration: 1) Community members must be open and transparent about nationality (citizenship) so others can fulfill their responsibilities; 2) all must recognize that nationality (citizenship) confers responsibilities that should be respected by the community; and 3) communities should talk about sensitive areas and design policies/structures that are inclusive where possible, but draw clearly defined and understood boundaries where necessary. If we do not address these problems, solutions will be imposed upon us. Without these steps, the risk is that distrust will grow, undermining the relationships and trust that make open collaboration so fruitful.

k H. Zhang. The 'post-truth' publication where Chinese students in America get their news. New Yorker, Aug. 19, 2019.

\section{Andrew A. Chien, EDITOR-IN-CHIE F}

From 2005-2010, Andrew Chien led Intel's international academic research and education engagements as well as its network of Open Collaborative Research Laboratories. $\mathrm{He}$ created two thriving industry-university collaborative research centers at UCSD and the University of Chicago. 